\title{
The Influence of Problem-Based Learning Model on Students' Learning Outcomes in Aceh Private University
}

\author{
Budi Rizka ${ }^{*}$, Lismalinda1 \\ 1 Universitas Iskandar Muda, Aceh, Indonesia \\ *e-mail: budirizka91@gmail.com
}

Article history: Received 15 December 2020; Accepted 31 March 2021; Available online 30 April 2021

\begin{abstract}
The aim of this study is to analyze the influence of using problem-based learning model in sociolinguistic learning on students learning outcomes of English Education at private universities in Aceh. This study used an experimental method with a research form that is pre-experimental design and one-group pretest-postest design experimental design. The population in this study were 20 students from private universities in Aceh. The sample in this study was the entire population of 20 students who were divided into an experimental group. The research instrument used was the learning outcome in the form of a multiplechoice test of 20 questions. The data collection technique in this study is a measurement technique. Hypothesis test results using $\mathrm{t}$-stat which is obtained in experimental group $\mathrm{t}$-stat $(-18.6)<\mathrm{t}$ Critical two-tail (2.093) with an average value of pre-test 59.75 and posttest 78 . From the results of these calculations it can be concluded that there is an effect of using problem-based learning models on learning outcomes in sociolinguistic learning of private university students in Aceh.
\end{abstract}

Copyright @ Universitas Pendidikan Ganesha. All rights reserved.

\section{Introduction}

Linguistics is a field of study that studies or discusses language, especialy the parts of language (phonemes, morphemes, words, sentences) and the relationship between these elements, including the nature and formation of these elements. One of the branches in the field of linguistics is sociolinguistics, which etymologically is a combination of the words socio and linguistics. The socio element is in line with the social, which is related to society, community groups, and social functions. So, sociolinguistics is the study or discussion of language in relation to speakers of that language as members of society. It can also be said that sociolinguistics studies and discusses social aspects of language, especially the differences (variations) that exist in language related to social (social) factors. Sociolinguistics is one of the compulsory subjects for students who are pursuing linguistics, one of which is English Language Education. Problem Based Learning is one of the learning approaches offered to improve students' abilities in understanding the sociolinguistics field. However, this method is only used by a small proportion of lecturers in Indonesia. The Problem Based Learning approach is a learning approach by exposing students to practical problems as a foothold in learning. In other words, the student problem-based learning approach is faced with existing problems to find solutions. Thus, students are active in attending lectures and no longer see sociolinguistics as a boring subject but on the contrary it will be fun. 
The lecture process is a process of developing student potential to become students in a comprehensive and integrated manner. Therefore, Lecturers are required to be able to understand various professional abilities in their fields. Furthermore, the delivery of lecture material must go through a learning approach that is appropriate for the purpose.

As the world of education develops, the implementation of lectures always changes because they are adjusted to the goals and needs of the course itself. In practice, each student has varying abilities during the lecture process. One of the courses that is able to equip students in capturing problems, thinking critically, creatively, and innovatively is Sociolinguistics. Sociolinguistics is one of the compulsory courses in the English Education Department. Through this course, students are expected to be able to understand and conduct literature studies in the scientific field of Sociolinguistics.

Thus, students are required to develop themselves continuously in honing their abilities. The demands of high ability and hard work have not been accompanied by a good learning process. Based on observations so far, Sociolinguistics lectures have not been running optimally. This is because the learning approach has not provided the flexibility for students to carry out activities in exploring ideas / ideas optimally, students tend to be less active and think minimally. This is due to the absence of a special approach for students to collect and conduct literature reviews in understanding a problem, so the lecture process is less in-depth.

Learning effectiveness is the learning result obtained after implementing the learning process. According to Riyanto (2003), the effectiveness of learning is defined as being effective or effective, or achieving goals or achieving learning objectives. Based on the opinion about the effectiveness of learning, it can be concluded that the effectiveness of learning is the learning result obtained through appropriate learning procedures. However, the effectiveness of learning is not automatically determined by momentary observation. According to Sinambela (2006), It is just said that learning is effective if it achieves the desired goals, both in terms of learning objectives and maximum student achievement. Some of the effectiveness can be viewed as: (a) Achievement of learning, (b) Achievement of the effectiveness of student activities (namely the achievement of ideal time students use to carry out each activity contained in the lesson plan), (c) Achievement of students' ability to improve learning, and positive response from students to learning. Not much different from the explanation of Wotruba and Wright (in Miarso, 2004), where indicators that can be used to determine the effectiveness of learning process are (a) good material organization, (b) effective communication, (c) mastery and enthusiasm for the material lessons, (d) a positive attitude towards students, (e) giving fair marks, (f) flexibility in the learning approach, and (g) good student learning outcomes.

The effectiveness of learning is a measure related to the level of success of a learning process. The indicator of effectiveness in this study is an increase in student learning outcomes which statistically shows a significant difference between before and after the application of the learning approach.

Problem Based Learning is a learning approach by exposing students to practical problems as a basis for learning (Wena, 2009). In sociolinguistic lectures using the Problem Based Learning approach, students are required to be faced with problems that must be solved. In the learning process, the situation or problem becomes the starting point for learning to understand concepts, principles, and develop problem-solving skills. According to Wina (2007), problembased learning does not expect students to only listen, take notes and then memorize the subject matter, but students must actively think, communicate, search and process data, and finally conclude. Thus, the Problem Based Learning Approach can be interpreted as a way of presenting teaching materials by making the problem a starting point for discussion in an effort to find solutions or answers by students so that they are actively involved in following the learning process. In this case, based on obkservation, the researchers got the students have many problem in learning Sosiolinguistics such as difficulties in achievement of the material. 
Therefore, the researchers wanted to apply the problem-based logging process in sociolinguistic learning to identify how the influence of problem-based learning on students learning outcome.

\section{Metode}

This research is a type of quantitative research with the aim of describing the effect of the Problem Based Learning approach on sociolinguistic learning outcomes in English Department students. This research was conducted on students of the English Department at Almuslim University, Bireuen. The approach used in this research is a quantitative approach. According to Sugiyono (2007) research data is in a quantitative approach, namely in the form of numbers and the researcher must analyze the data using statistics.

Meanwhile, the method applied in this research is the pre-experimental method with one group preest-posttest design. Ary (2010) said that this pre-experimental study used one group as the sample, namely the experimental group that was given treatment, while the control group was not used. Hartas (2010) defines population as a group of individuals or organizations that have the same characteristics that are of interest to research. In other words, the population is the group to which the researcher wants to generalize the findings obtained to the research sample. Thus, the population in this study were all students of the English Department at Almuslim. This study uses a type of pre-experimental method called the One-Group PretestPosttest Design. According to (Ary et al, 2010), there are three steps in applying the One-Group Pretest-Posttest Design: (1) giving a pretest to measure the dependent variable, (2) applying experimental $\mathrm{X}$ to the subject, (3) giving a posttest to re-measuring the dependent variable .

After the population is determined, the study sample is selected. Hartas (2010) also defines the research sample as a part or subgroup of the population that the researcher wants to study. How the research sample is selected is very important for the validity of a study. In this study, the researcher chose the research subject using one of the sampling procedures, namely purposive sampling. Johnson and Christensen (2014) concluded that in purposive sampling, researchers determine the characteristics of the population of interest and then try to find individuals who have these characteristics. In short, purposive sampling is a sampling technique with a purpose. Thus, the sample of this study were students of the fourth semester of the English Department at Almuslim University who took Sociolinguistics courses in the English Department according to the curriculum at the college.

In this study, data collection was carried out in six meetings. In this study, data collection during the learning process was carried out by means of a test as a data collection technique. In using the test as a measure of the achievement of student learning outcomes in the Sociolinguistics subject. Researchers compile pre-test and post-test questions. The questions are adjusted to the syllabus at the college in the Sociolinguistics course. The pre-test and post-test questions are in the form of essay questions that are validated by giving pre-test questions to the subject of the validation of the questions, namely students of the English Department at Serambi Mekkah University in Banda Aceh. Furthermore, the validation results are processed using the validity and reliability formulas. After seeing the reality and validity of the questions, these questions can already be given to the research subjects, namely students of the Department of English at Almuslim University. The Data analyzing of the effect of applying the type of problem based learning on student learning outcomes, researchers used the t-test with the polled variance formula (Sugiyono, 2014).

\section{Result and Discussion}

This research was conducted on students of the English Education Department at Almuslim University as an experimental group, where students of the Department of English Education at Almuslim University used Problem Base Learning in the context of students' daily language according to the learning material. Before being given learning material being taught, 
the experimental group was first given a pre-test. The purpose of the pre-test was to determine the level of ability of students in both groups. After the treatment with Problem Base Learning is carried out, a post test is carried out to determine the learning outcomes after the treatment is carried out. The pre-test and post-test scores in Experiment groups A and B can be seen in Figure 1.
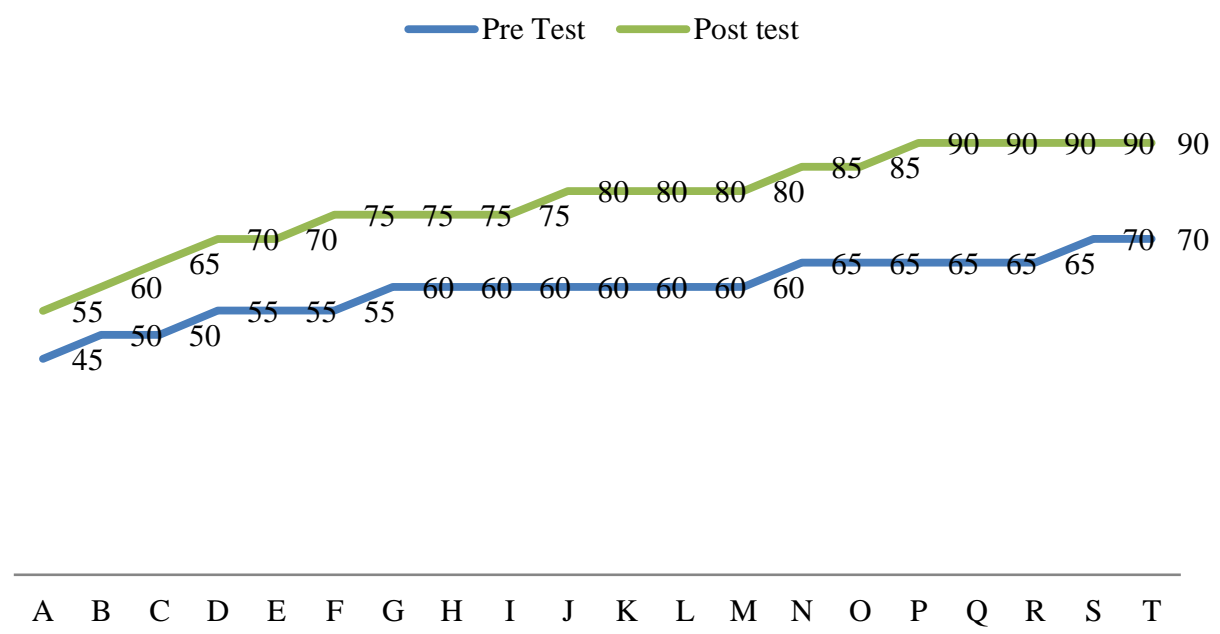

Figure 1. Test Results Experiment Group

The data from the pre-test and post-test results analyzed and can be seen in table 1 below:

Table 1

Experiment Class Frequency Distribution.

\begin{tabular}{|c|c|c|c|c|}
\hline \multirow{2}{*}{ No } & \multicolumn{2}{|c|}{ Pre-test Result } & \multicolumn{2}{|c|}{ Post-test Result } \\
\hline & Score & Frequency & Score & Frequency \\
\hline 1 & $45-49$ & 1 & $55-61$ & 2 \\
\hline 2 & $50-54$ & 2 & $62-68$ & 1 \\
\hline 3 & $55-59$ & 3 & $69-75$ & 6 \\
\hline 4 & $60-64$ & 7 & $76-82$ & 4 \\
\hline 5 & $65-69$ & 5 & 83-89 & 2 \\
\hline 6 & $70-74$ & 2 & $90-96$ & 5 \\
\hline \multicolumn{2}{|c|}{ Total } & 20 & Total & 20 \\
\hline \multicolumn{2}{|c|}{ Avarage } & 59.75 & Avarage & 78 \\
\hline \multicolumn{3}{|c|}{ t-Test: Paired Two Sample for Mean } & Pre-Test & Post-Test \\
\hline \multicolumn{3}{|c|}{ Mean } & 59.75 & 78 \\
\hline \multicolumn{3}{|c|}{ Variance } & 43.3552632 & 106.31579 \\
\hline \multicolumn{3}{|c|}{ Observations } & 20 & 20 \\
\hline \multicolumn{3}{|c|}{ Pearson Correlation } & 0.96127641 & \\
\hline \multicolumn{3}{|c|}{ Hypothesized Mean Difference } & 0 & \\
\hline \multicolumn{3}{|c|}{ df } & 19 & \\
\hline \multicolumn{3}{|c|}{ t Stat } & -18.653192 & \\
\hline \multicolumn{3}{|c|}{$\mathrm{P}(\mathrm{T}<=\mathrm{t})$ one-tail } & $5.6329 \mathrm{E}-14$ & \\
\hline \multicolumn{3}{|c|}{ t Critical one-tail } & 1.72913281 & \\
\hline \multicolumn{3}{|c|}{$\mathrm{P}(\mathrm{T}<=\mathrm{t})$ two-tail } & $1.1266 \mathrm{E}-13$ & \\
\hline \multicolumn{3}{|c|}{ t Critical two-tail } & 2.09302405 & \\
\hline
\end{tabular}


Based on Table 1, the results of the pre-test and post-test calculations in Experiment group showed a significant difference between before and after being treated in the class where the Post-test average in the experimental group is higher than the Pre-test. It can be seen that the Tstat in the experimental group is smaller than the T-critical two tiles, so it can be concluded that $\mathrm{H} 1$ is acceptable, meaning that the Problem Base Learning model is able to improve student learning outcomes in sociolinguistic learning.

\section{Conclusion}

Student learning outcomes of experimental class Based on the $t$ test analysis or hypothesis testing, it was obtained tstat $(-18.6)<$ Critical two-tail $(2.093)$ with an average value of pre-test 59.75 and posttest 78. It means significant, so it can be concluded that Ha is accepted or approved and Ho is rejected. This means that there is an effect of the application of the problem based learning model on student learning outcomes in sociolinguistic learning in English language education students from private university in Aceh. Learning by applying the problem based learning model contributes a significant effect on learning outcome.

\section{References}

Ary, D., Jacobs, L. C., Sorensen, C., \& Razavieh, A. (2010). Introduction to Research in Education (8th Ed.). California: Wardworth.

Hartas, D. (2010). Educational Research and Inquiry. London: Continuum International Publishing Group.

Johnson, R. B., \& Christensen, L. (2014). Educational Research: Quantitative, Qualitative and Mixed Approaches. Thousand Oaks: SAGE.

Miarso, Y. (2004). Menyemai Benih Teknologi Pendidikan. Jakarta: Prenada Media.

Riyanto, A. (2003). Proses Belajar Mengajar Efektif di Perguruan Tinggi. Bandung: Yapemdo.

Rusman. (2010). Model Model Pembelajaran. Bandung: Rajawali Pers.

Setia, R. F. (2014). Penerapan Pembelajaran Berbasis Masalah Dalam Membaca Ekstensif Teks Nonsastra Pada Siswa Kelas X SMA. Bahtera Bahasa: Antologi Pendidikan Bahasa dan Sastra Indonesia. Pembelajaran Kebahasaan: No. 12.

Sinambela, N.J.M.P. 2006. Keefektifan Model Pembelajaran Berdasarkan Masalah (Problem-Based Instruction) Dalam Pembelajaran Matematika untuk Pokok Bahasan Sistem Linear dan Kuadrat di Kelas X SMA Negeri 2 Rantau Selatan Sumatera Utara. Surabaya: Program Pasca Sarjana Universitas Negeri Surabaya.

Sugiyono. (2007). Metodologi Penelitian. Bandung: Alfabeta.

Sugiyono. (2014). Statistik untuk Penelitian. Bandung: Alfabeta.

Trianto. (2010). Mendesain Model Pembelajaran Inovatif-Progresif. Jakarta: Kencana Prenada Media Grup.

Wena, M. (2009). Startegi Pembelajaran Inovatif: Suatu Tinjauan Konseptual Operasional. Jakarta: Bumi Aksara.

Wina, S. (2007). Strategi Pembelajaran Berorientasi Standar Proses Pendidikan. Jakarta: Kencana Prenada Media Group. 